\title{
PHOTOSYNTHETIC RESPONSES TO IRRADIANCE IN THREE FOREST UNDERSTORY SPECIES OF THE $\mathrm{C}_{4}$ GRASS GENUS MUHLENBERGIA ${ }^{1}$
}

\author{
MARIAN SMITH ${ }^{2}$ AND CRAIG E. MARTIN \\ Department of Botany, University of Kansas, Lawrence, Kansas 66045
}

\begin{abstract}
Three species of the $\mathrm{C}_{4}$ grass genus Muhlenbergia-M. frondosa, $M$. sobolifera, and $M$. schreberi-were collected from forest understory habitats in Kansas and grown in a growth chamber at 1,500,150, and 15$25 \mu \mathrm{mol} \mathrm{m} \mathrm{m}^{-2} \mathrm{~s}^{-1}$ photosynthetic photon flux density (PPFD). Assimilation (A), conductance to $\mathrm{CO}_{2}$, intercellular $\mathrm{CO}_{2}$ concentration, chlorophyll (chl) concentrations, and photosystem I electron-transport capacity were determined and compared with results for $M$. cuspidata, which occurs only in open, prairie areas. All of the shade species exhibited more shade tolerance than the prairie species: they had lower maximum $\mathrm{A}$, saturation of $\mathrm{A}$, and photosystem I electron transport with respect to PPFD, higher quantum yields that increased with decreasing growth PPFD, and increasing chl concentrations with decreasing PPFD.
\end{abstract}

\section{Introduction}

Plants from shaded habitats generally have lower photosynthetic rates than sun plants at saturating PPFD, but relatively high rates at low PPFD (BJÖRKMAN and HOLMGREN 1963). When grown at a range of PPFD, sun and shade plants respond differently, indicating adaptation to a particular PPFD (BJÖRKMAN and HOLMGREN 1963; BJÖRKMAN et al. 1972; Agata et al. 1985).

Shade plants often have greater chl concentrations on a weight basis and lower chl a/b ratios than sun plants (BOARDMAN 1977; BJÖRKMAN 1981). Both characteristics are thought to enhance light capture in environments with low PPFD. Therefore, an examination of chl concentrations may reveal a physiological adaptation to a particular level of PPFD.

Higher rates of A at light saturation in sun plants may be a consequence of changes in internal leaf morphology (NOBEL 1976; NOBEL and LONGSTRETH 1981; LONGSTRETH et al. 1985). In some species, a strong positive correlation between photosynthetic rate on a leaf surface area basis and $\mathrm{A}_{\text {mes }} /$ A (mesophyll cell surface area to leaf surface area) has been demonstrated (NoBEL et al. 1975; ÖQUIST et al. 1982). Other species have not always shown such a strong correlation between the two factors (Chabot and Chabot 1977; LONGSTRETH et al. 1981).

Another indicator of adaptation to light in plants is the rate of photosynthetic electron transport. Increased PPFD during growth substantially in-

${ }^{1}$ Abbreviations: $\mathrm{A}$, assimilation; $\mathrm{A}_{\text {mes }} / \mathrm{A}$, area of the mesophyll/leaf area; chl, chlorophyll; $\mathrm{c}_{\mathrm{i}}$, intercellular $\mathrm{CO}_{2}$ concentration; $\mathrm{g}_{\mathrm{c}}$, conductance to $\mathrm{CO}_{2}$; LSD, least significant difference; MV, methyl viologen; PPFD, photosynthetic photon flux density.

${ }^{2}$ Current address and address for correspondence and reprints: Department of Biological Sciences, Southern Illinois University, Edwardsville, Illinois 62026-1001.

Manuscript received July 1986; revised manuscript received March 1987. creases the capacity for light-saturated electron transport in many species (BJÖRKMAN et al. 1972; ÖQUIST and HeLLGREN 1976). Furthermore, shade plants have lower electron-transport capacities than sun plants (BJÖRKMAN et al. 1972; BOARDMAN 1972).

$\mathrm{C}_{4}$ plants have a higher ATP requirement than $\mathrm{C}_{3}$ plants and exhibit characteristics typical of sun plants (PEARCY and EHLERINGER 1984). However, recent work with $\mathrm{C}_{4}$ plants collected from forest understories indicates that the $\mathrm{C}_{4}$ syndrome may not impose an inherent limitation on the ability of a plant to adjust to a wide range of light levels (BROWN 1977; PEARCY et al. 1982; WINTER et al. 1982; WARD and WOOLHOUSE 1986).

To provide a better understanding of the potential for shade tolerance in $\mathrm{C}_{4}$ plants, the photosynthetic responses of three species of the $\mathrm{C}_{4}$ grass genus Muhlenbergia collected from understory habitats- $M$. frondosa, $M$. sobolifera, and $M$. schreberi-were compared with those of a related species, $M$. cuspidata, which is confined to exposed environments. Photosynthesis, chl concentrations, and photosystem I electron-transport capacity were measured as indicators of the degree of photosynthetic adaptability to PPFD.

\section{Material and methods}

Muhlenbergia frondosa (Poir.) Fern., M. sobolifera (Muhl.) Trin., and M. schreberi Gmel. were collected from a forest understory and $M$. cuspidata (Torre.) Rydb. from an open prairie. Collection sites and details of growth conditions are described by SMITH and MARTIN (1987).

The collected plants were potted and grown in a growth chamber under three light regimes: 1,500, 150 , and $15-25 \mu \mathrm{mol} \mathrm{m}^{-2} \mathrm{~s}^{-1}$ for 30-40 days for gas-exchange measurements, 28 days for pigment analyses, and 28-35 days for photosystem I measurements. Plants were maintained under a 12 -h photoperiod, 30/25 C day/night, and 15\%/25\% day/night RH. 


\section{Photosynthetic GAS EXCHANGe}

Photosynthetic responses to instantaneous PPFD were determined for all species with a gas-exchange system identical with that described in MARTIN and ZEE (1983), except that a water-jacketed polycarbonate chamber with an $8.75-\mathrm{cm}^{3}$ volume was used. The flow rate through the chamber was ca. $1.5 \mathrm{~L} \mathrm{~min}^{-1}$, and the turnover time for chamber air was ca. 0.35 s. Maximum air turbulence in the chamber was maintained by varying the angles and positions of the 10 air-inlet and -outlet holes. Light was provided by a $400-\mathrm{W}$ multivapor metal halide lamp with a spectral irradiance peak at $600 \mathrm{~nm}$ and was decreased with layers of cheesecloth (BROwN 1968). PPFD levels were determined at the chamber surface (transmittance ca. 90\%) with a LI-COR (Lincoln, Neb.) LI-190SB quantum sensor and LI-185B meter.

Gas-exchange measurements were taken at 11 PPFD levels after allowing the system to achieve a steady-state rate of gas exchange at each PPFD level: $0,10,20,25,65,105,150,250,300,700$, and $1,500 \mu \mathrm{mol} \mathrm{m} \mathrm{m}^{-2} \mathrm{~s}^{-1}$. This usually occurred within $10-45 \mathrm{~min}$. If the rate did not reach steady state within $45 \mathrm{~min}$, the PPFD level was increased. Experiments were initiated in darkness, and PPFD was increased incrementally to $1,500 \mu \mathrm{mol} \mathrm{m} \mathrm{m}^{-2} \mathrm{~s}^{-1}$ and then lowered to several intermediate levels to check for irreversible damage to the leaves. Such damage was never observed. Leaf temperature was maintained at $30 \mathrm{C}$; air temperature varied from 26 to $30 \mathrm{C}$, and vapor pressure deficit from 1.75 to $2.80 \mathrm{kPa}$ (MArtin and ZeE 1983). Mean $\mathrm{CO}_{2}$ concentration was $354 \mu \mathrm{L} \mathrm{L}^{-1}(\mathrm{SD}=10$, no. $=108)$.

Gas exchange was measured on three attached leaves per plant from three plants for each species at each growth PPFD. The portions of the attached plants outside the chamber were covered with cheesecloth, and the plants were watered as needed during measurements to protect them against heat and desiccation damage.

On completion of the gas-exchange measurements, the leaves were removed from the chamber to measure leaf area with a LI-COR LI-3000 leaf area meter. Chl concentrations were determined. $\mathrm{CO}_{2-}^{-}$and $\mathrm{H}_{2} \mathrm{O}$-exchange data were calculated (SĚSTÁK et al. 1971); and A, $\mathrm{g}_{\mathrm{c}}$, and $\mathrm{c}_{\mathrm{i}}$ were calculated using equations from FARQUHAR and VON CAEMMERER (1982). Quantum yields for $\mathrm{CO}_{2}$ uptake were calculated as the slope of the linear relationship between incident PPFD $\left(0-150 \mu \mathrm{mol} \mathrm{m}{ }^{-2}\right.$ $\mathrm{s}^{-1}$ ) and $\mathrm{CO}_{2}$ exchange.

All gas-exchange data were analyzed using a twoway ANOVA (SPSS ${ }^{x}$, Chicago, Ill.), and mean values for $A, g_{c}$, and $c_{i}$ at maximum instantaneous PPFD were compared for LSD (SOKAL and ROHLF 1981). Statistical difference was inferred when $P$ $<.05$.

\section{$\mathrm{A}_{\text {mes }} / \mathrm{A}$ DETERMINATIONS}

Fresh leaf sections were prepared to determine $\mathrm{A}_{\text {mes }} / \mathrm{A}$ ratios (SMITH and MARTIN 1987). Measurements of $\mathrm{A}_{\text {mes }} / \mathrm{A}$ ratios for $M$. frondosa, $M$. sobolifera, and $M$. schreberi were made, assuming the cells to be spherical (NoBEL et al. 1975). For $M$. cuspidata, which has radiating cylindrical mesophyll surrounding each bundle sheath, cells were assumed to be cylinders with hemispherical ends (NoBEL et al. 1975). Ratios were calculated, including interstitial mesophyll cells on either side of the bundle sheaths. $A_{\text {mes }} / A$ ratios were analyzed using the Kruskal-Wallace test for nonparametric data, and means were compared using the MannWhitney $U$-test (SOKAL and RoHLF 1981). Statistical difference was inferred when $P<.05$.

\section{Pigment ANALYSES}

The first mature leaf from three to 10 plants of each species at each light level was clipped; its area was measured; and chl determinations made (MARTIN et al. 1985). All pigment data were statistically analyzed by ANOVA, and means were compared for LSD (SoKAL and RoHLF 1981). Statistical difference was inferred when $P<.05$.

\section{PHOTOSYNTHETIC ELECTRON-TRANSPORT CAPACITY}

Preparation of chloroplasts for measurement of photosystem I activity followed ROBINSON and Yocum (1980). Leaves (1-5 g) were removed from mature plants, cut into small pieces, and ground at $5 \mathrm{C}$ with a mortar and pestle in a minimal amount of extraction buffer ( $\mathrm{pH} 7.5)$, consisting of $0.4 \mathrm{M}$ sucrose, $20 \mathrm{mM}$ HEPES, $5 \mathrm{mM} \mathrm{MgCl}_{2}, 0.15 \mathrm{M}$ $\mathrm{NaCl}$, and $0.2 \% \mathrm{BSA}$ (RoBINSON and Yocum 1980). The slurry was ground until examination under a light microscope revealed that the bundle sheaths were obliterated, filtered through four layers of cheesecloth, and centrifuged at $200 \mathrm{~g}$ for $2 \mathrm{~min}$ at $5 \mathrm{C}$. The pellet was discarded; the supernatant was spun at $1,475 \mathrm{~g}$ for $10 \mathrm{~min}$, recovered, and centrifuged again at $1,475 \mathrm{~g}$ for an additional $10 \mathrm{~min}$. The supernatant was then frozen at $-80 \mathrm{C}$ and stored until needed (1-6 wk), whereupon it was thawed on ice and chl concentration was determined. No effects of cold storage were evident; full-scale absorption spectra revealed no peaks attributable to pheophytin.

The photoreduction of $\mathrm{MV}$ as an indicator of photosystem I electron-transport capacity was determined (KATOH 1972) by following the absorption of oxygen in a reaction mixture ( $\mathrm{pH} 7.8)$ containing $20 \mathrm{mM}$ Tris $\mathrm{HCl}, 0.1 \mathrm{mM} \mathrm{MV}, 0.04 \mathrm{mM}$ 2,6 dichlorophenolindophenol (DCIP), 2mM ascorbate, $10 \mu \mathrm{M}$ (3-[3,4-dichlorophenyl])-1, 1-dimethylurea (DCMU), and $1 \mathrm{mM}$ sodium azide. Nine $\mathrm{mL}$ of the above reaction mixture, $80 \mu \mathrm{g} \mathrm{chl}$, and sufficient distilled water to complete the volume 
were placed in an $18-\mathrm{mL}$ glass water-jacketed chamber and stirred continuously with a magnetic stir bar. Oxygen absorption was measured with a YSI (Yellow Springs, Oh.) R-5521-00 oxygen electrode and R-5514 meter at nine PPFD levels $(0,5,10,25,40,80,150,500$, and $1,500 \mu \mathrm{mol}$ $\mathrm{m}^{-2} \mathrm{~s}^{-1}$ ). Light (Bausch and Lomb optical unit with a 500-W lamp) was measured at the outer surface of the chamber. The light beam passed through a heat filter of $30 \mathrm{~cm}$ water that maintained the reaction mixture at 21-23 C during measurements. Three plants of each species at each growth PPFD were analyzed; the chamber was flushed with deionized water between experiments. All data were statistically analyzed in the same manner as in the gas-exchange measurements.

\section{Results}

\section{Photosynthetic Gas eXChange}

Growth PPFD had a significant effect on photosynthetic responses to PPFD in Muhlenbergia frondosa (fig. 1A), $M$. schreberi (fig. $3 A$ ), and $M$.

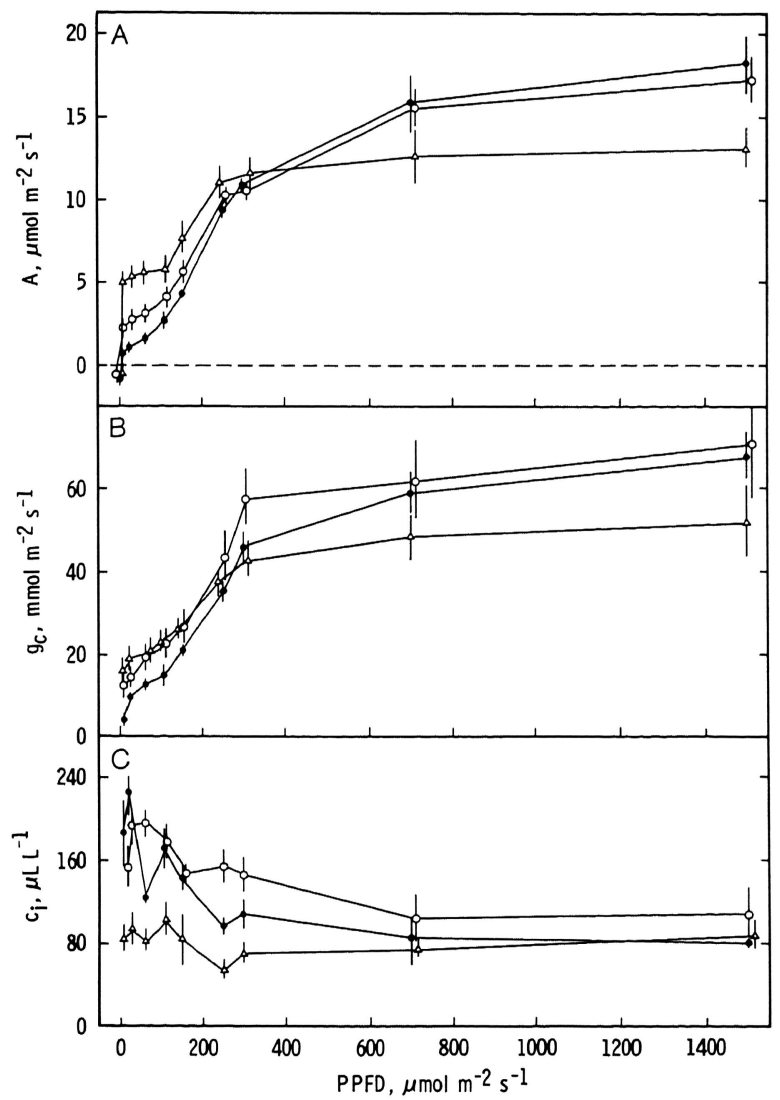

FIG. 1.-A, Assimilation rate (A); $B$, leaf conductance $\left(g_{c}\right)$; and $C$, intercellular $\mathrm{CO}_{2}$ concentration $\left(c_{i}\right)$ as functions of PPFD in Muhlenbergia frondosa. Plants were grown for 30-40 days at the following PPFD levels: 0 . High $=1,500 \mu \mathrm{mol} \mathrm{m}^{-2} \mathrm{~s}^{-1}$. $\mathrm{O}$, Medium $=150 \mu \mathrm{mol} \mathrm{m}^{-2} \mathrm{~s}^{-1} . \Delta$, Low $=15-25 \mu \mathrm{mol} \mathrm{m}^{-2}$ $\mathrm{s}^{-1}$. Data are means and SE of three plants.

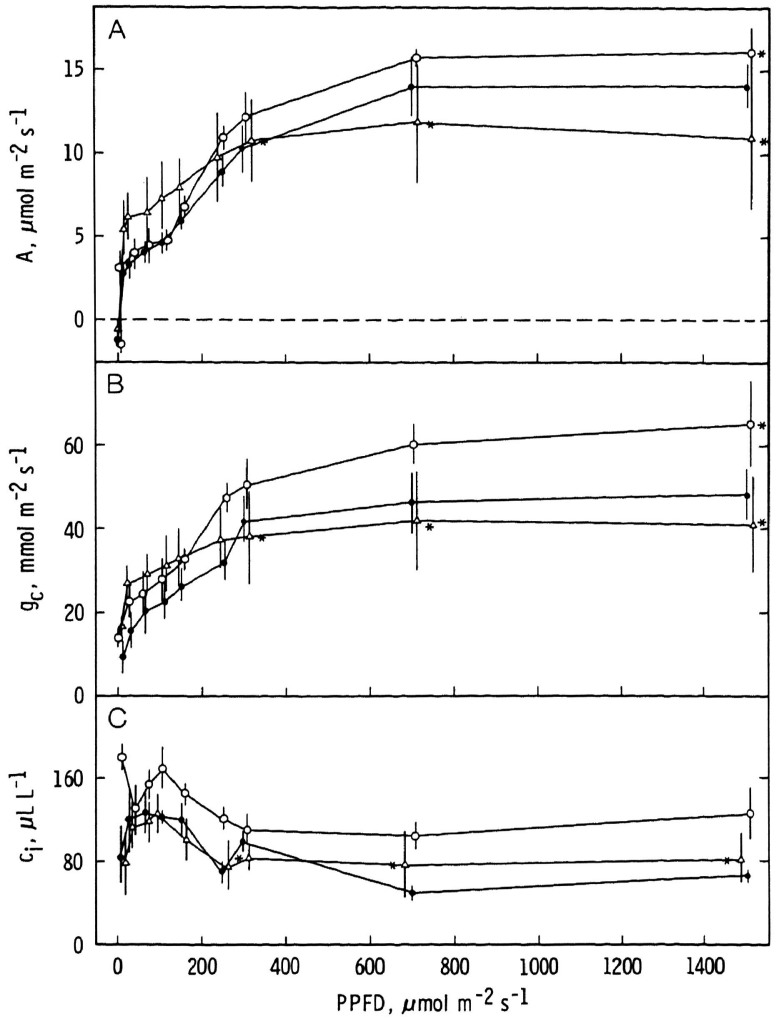

FIG. 2.- $A$, Assimilation rate (A); $B$, leaf conductance $\left(g_{c}\right)$; and $C$, intercellular $\mathrm{CO}_{2}$ concentration $\left(c_{i}\right)$ as functions of PPFD in Muhlenbergia sobolifera. Plants were grown for 30-40 days at the following PPFD levels: $\bullet$ High $=1,500 \mu \mathrm{mol} \mathrm{m}^{-2} \mathrm{~s}^{-1}$. $O$, Medium $=150 \mu \mathrm{mol} \mathrm{m}^{-2} \mathrm{~s}^{-1} . \Delta$, Low $=15-25 \mu \mathrm{mol} \mathrm{m}^{-2}$ $\mathrm{s}^{-1}$. Data are means and $\mathrm{SE}$ of three plants. Asterisks indicate non-steady-state results.

cuspidata (fig. 4A), but not in $M$. sobolifera (fig. 2A). Light saturation of photosynthesis occurred at ca. $250-400 \mu \mathrm{mol} \mathrm{m}{ }^{-2} \mathrm{~s}^{-1}$ for $M$. frondosa, $M$. sobolifera, and $M$. schreberi grown at all PPFD levels and for $M$. cuspidata grown at medium and low PPFD. Muhlenbergia cuspidata grown at high PPFD failed to show photosynthetic saturation with respect to PPFD.

Maximum A in $M$. frondosa was higher at high instantaneous PPFD in plants grown at high and medium PPFD than at low PPFD (fig. 1A). Muhlenbergia schreberi grown at medium PPFD exhibited higher maximum A (fig. $3 A$ ) compared to plants grown at high and low PPFD, whereas plants of $M$. cuspidata grown at high PPFD exhibited higher rates than at medium and low PPFD (fig. $4 A$ ).

In plants from all growth regimes, $\mathrm{g}_{c}$ generally increased in conjunction with $A$ in response to increasing instantaneous PPFD in all four species (figs. $1 B, 2 B, 3 B, 4 B$ ). Muhlenbergia frondosa (fig. $1 B$ ) and $M$. schreberi (fig. $3 B$ ) grown at high and medium PPFD had equally high maximum $\mathrm{g}_{\mathrm{c}}$. However, $g_{c}$ was highest in plants grown at medium 


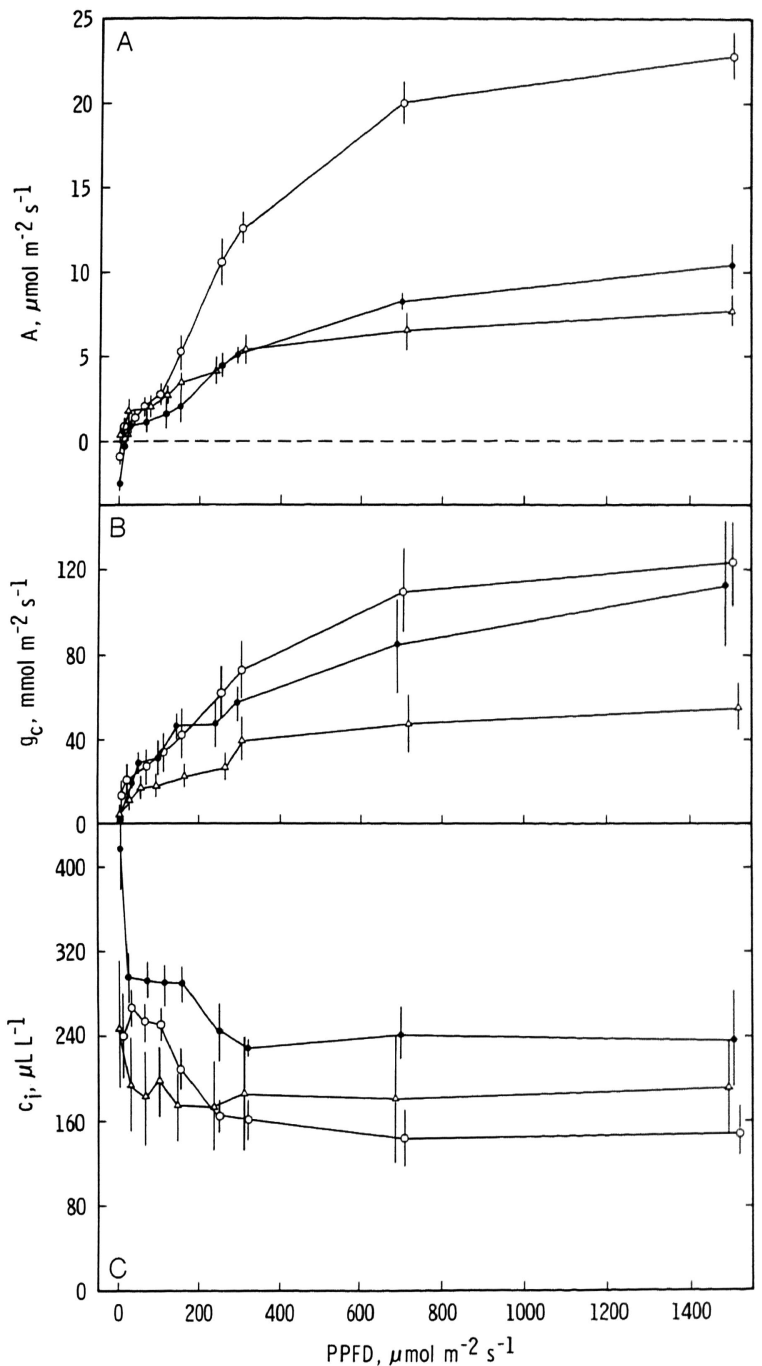

FIG. 3.-A, Assimilation rate (A); $B$, leaf conductance $\left(g_{c}\right)$; and $C$, intercellular $\mathrm{CO}_{2}$ concentration $\left(c_{i}\right)$ as functions of PPFD in Muhlenbergia schreberi. Plants were grown for 30-40 days at the following PPFD levels: 0 , High $=1,500 \mu \mathrm{mol} \mathrm{m}^{-2} \mathrm{~s}^{-1}$ $O$, Medium $=150 \mu \mathrm{mol} \mathrm{m}^{-2} \mathrm{~s}^{-1} \cdot \Delta$, Low $=15-25 \mu \mathrm{mol} \mathrm{m}^{-2}$ $\mathrm{s}^{-1}$. Data are means and SE of three plants.

PPFD in $M$. sobolifera (fig. $2 B$ ) and highest in $M$. cuspidata in plants grown at high PPFD (fig. $4 B$ ).

Growth PPFD did not have a significant effect on $\mathrm{c}_{\mathrm{i}}$ (figs. $1 C, 2 C, 3 C, 4 C$ ). Generally, $\mathrm{c}_{\mathrm{i}}$ was high at very low instantaneous PPFD and then decreased and remained constant at instantaneous PPFD levels above ca. $200 \mu \mathrm{mol} \mathrm{m}{ }^{-2} \mathrm{~s}^{-1}$.

Quantum yields increased with decreasing growth PPFD in $M$. frondosa and $M$. sobolifera (table 1). Quantum yield was highest at medium-growth PPFD in $M$. schreberi but highest at high PPFD in $M$. cuspidata.

$\mathrm{A}_{\text {mes }} /$ A ratios in $M$. cuspidata and $M$. frondosa increased with increasing growth PPFD (table 1). In $M$. schreberi, $\mathrm{A}_{\text {mes }} / \mathrm{A}$ was not different between the medium and low PPFD levels, and, in $M$. so- bolifera, $\mathrm{A}_{\text {mes }} / \mathrm{A}$ was different only between plants from the high and medium PPFD levels.

\section{PIGMENT RESPONSES TO PPFD}

Total chl concentration increased in $M$. frondosa and $M$. sobolifera with decreasing PPFD (table 2), and $\mathrm{a} / \mathrm{b}$ ratios declined at the lowest PPFD level. In both $M$. schreberi and $M$. cuspidata, chl concentration increased from high to medium PPFD and then decreased at the lowest PPFD level. Chl $\mathrm{a} / \mathrm{b}$ ratios in $M$. schreberi were highest at high PPFD but remained unchanged in $M$. cuspidata at the three PPFD levels.

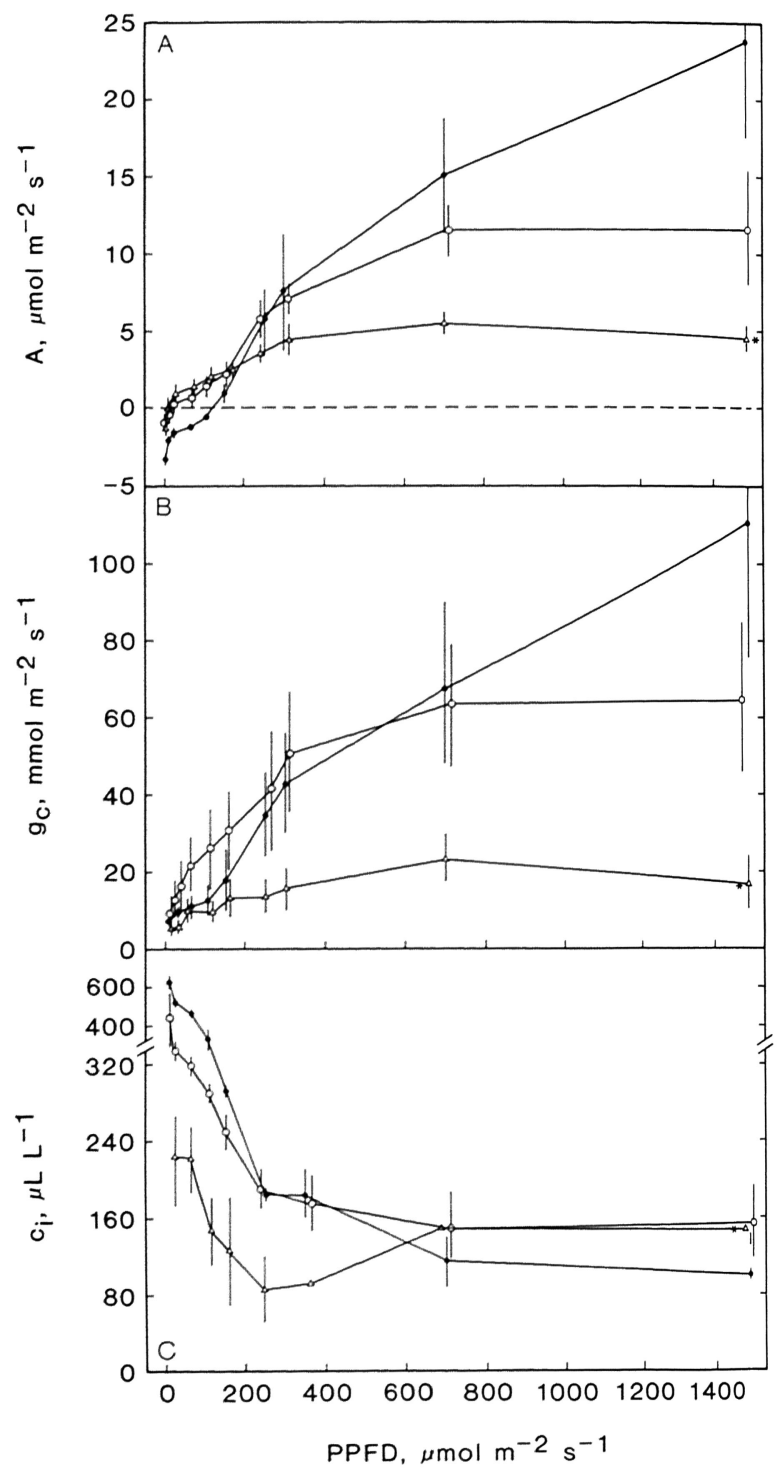

FIG. 4.- $A$, Assimilation rate (A); $B$, leaf conductance $\left(g_{c}\right)$; and $C$, intercellular $\mathrm{CO}_{2}$ concentration $\left(c_{i}\right)$ as functions of PPFD in Muhlenbergia cuspidata. Plants were grown for 30-40 days at the following PPFD levels: $\bullet$ High $=1,500 \mu \mathrm{mol} \mathrm{m}^{-2} \mathrm{~s}^{-1}$ $\bigcirc$, Medium $=150 \mu \mathrm{mol} \mathrm{m}^{-2} \mathrm{~s}^{-1} . \Delta$, Low $=15-25 \mu \mathrm{mol} \mathrm{m}^{-2}$ $\mathrm{s}^{-1}$. Data are means and SE of three plants. Asterisks indicate non-steady-state results. 
TABLE 1

EFFECT OF PPFD ON QUANTUM YIELD AND $\mathrm{A}_{\text {mes }} / \mathrm{A}$ IN THREE UNDERSTORY AND ONE PRAIRIE SPECIES OF A $\mathrm{C}_{4}$ GRASS AFTER 28-35 DAYS OF GROWTH IN A GROWTH CHAMBER

\begin{tabular}{|c|c|c|c|}
\hline \multirow[b]{3}{*}{ SPECIES } & \multicolumn{3}{|c|}{ GROWTH PPFD $\left(\mu \mathrm{mol} \mathrm{m}{ }^{-2} \mathrm{~s}^{-1}\right)$} \\
\hline & HIGH PPFD & MEDIUM PPFD & Low PPFD \\
\hline & $\begin{array}{c}1,500 \mu \mathrm{mol} \mathrm{m}{ }^{-2} \mathrm{~s}^{-1} \\
\bar{X} \pm \mathrm{SE} \text { (No.) }\end{array}$ & $\begin{array}{c}150 \mu \mathrm{mol} \mathrm{m}^{-2} \mathrm{~s}^{-1} \\
\bar{X} \pm \mathrm{SE} \text { (No.) }\end{array}$ & $\begin{array}{c}15-25 \mu \mathrm{mol} \mathrm{m}^{-2} \mathrm{~s}^{-1} \\
\bar{X} \pm \mathrm{SE} \text { (No.) }\end{array}$ \\
\hline \multicolumn{4}{|l|}{ Muhlenbergia frondosa: } \\
\hline Quantum yield & $.034(3)$ & $.044(3)$ & $.053(3)$ \\
\hline $\mathrm{A}_{\text {mes }} / \mathrm{A}$ ratio & $6.71 \pm .35 a(5)$ & $5.17 \pm .14 \mathrm{~b}(8)$ & $4.51 \pm .09 c(7)$ \\
\hline \multicolumn{4}{|l|}{ M. sobolifera: } \\
\hline Quantum yield & $.046(3)$ & $.053(3)$ & $.057(3)$ \\
\hline$\AA_{\text {mes }} /$ A ratio & $6.02 \pm .22 \mathrm{a}(7)$ & $5.48 \pm .09 \mathrm{~b}(5)$ & $5.19 \pm .17 \mathrm{~b}(10)$ \\
\hline \multicolumn{4}{|l|}{ M. schreberi: } \\
\hline Quantum yield & $.023(3)$ & $.040(3)$ & $.023(3)$ \\
\hline $\mathrm{A}_{\text {mes }} / \mathrm{A}$ ratio & $5.79 \pm .16 a(10)$ & $5.04 \pm .19 \mathrm{a}(4)$ & $4.93 \pm .16 \mathrm{~b}(7)$ \\
\hline \multicolumn{4}{|l|}{ M. cuspidata: } \\
\hline Quantum yield & $.028(3)$ & $.022(3)$ & $.022(3)$ \\
\hline $\mathrm{A}_{\text {mes }} / \mathrm{A}$ ratio & $20.72 \pm .43 a(4)$ & $18.88 \pm .31 b(5)$ & $15.63 c(1)$ \\
\hline
\end{tabular}

NOTE.-Only means with different letters differ significantly $(P<.05$, Mann-Whitney $U$-test). Sample sizes are in parentheses after the name of each species.

\section{PHOTOSYNTHETIC ELECTRON TRANSPORT}

Rates of oxygen uptake increased with increasing growth PPFD in $M$. frondosa and $M$. cuspidata (fig. $5 A, 5 D$ ) but not in $M$. sobolifera or $M$. schreberi (fig. 5B, 5C). The maximum rate of oxygen absorption was higher for $M$. frondosa grown at high and medium PPFD than in plants grown at low PPFD (fig. $5 A$ ), and in $M$. cuspidata the highest uptake rates occurred in plants grown at high PPFD (fig. 5D). In addition, maximum oxygenuptake rates for $M$. cuspidata were twice as high as those of the other species. Although oxygen-uptake rates began to saturate at ca. $200 \mu \mathrm{mol} \mathrm{m} \mathrm{m}^{-2}$ $\mathrm{s}^{-1}$ for all species at all growth PPFD levels, plants of $M$. frondosa and $M$. cuspidata from high PPFD continued to exhibit a gradual increase in oxygen uptake up to the highest PPFD level (fig. $5 A, 5 D$ ).

\section{Discussion}

\section{Photosynthetic GAS EXCHANGE}

The photosynthetic responses of Muhlenbergia cuspidata to growth PPFD are consistent with reports of a number of $\mathrm{C}_{4}$ sun plants (BOARDMAN 1977; BJÖRKMAN 1981). Because $c_{i}$ did not differ significantly among growth PPFD levels, plants of $M$.

TABLE 2

EFFECT OF PPFD ON chl CONTENT ( $\mathrm{mg} \mathrm{g}^{-1} \mathrm{DW}$ ) AND chl a/b RATIOS IN THREE UNDERSTORY SPECIES AND ONE PRAIRIE SPECIES OF A $\mathrm{C}_{4}$ GRASS

\begin{tabular}{|c|c|c|c|}
\hline \multirow[b]{3}{*}{ SPECIES } & \multicolumn{3}{|c|}{ Growth PPFD $\left(\mu \mathrm{mol} \mathrm{m}{ }^{-2} \mathrm{~s}^{-1}\right)$} \\
\hline & HIGH PPFD & MEDIUM PPFD & Low PPFD \\
\hline & $\begin{array}{c}\overline{1,500 \mu \mathrm{mol} \mathrm{m}^{-2} \mathrm{~s}^{-1}} \\
\bar{X} \pm \mathrm{SE}\end{array}$ & $\begin{array}{c}150 \mu \mathrm{mol} \mathrm{m} \mathrm{m}^{-2} \mathrm{~s}^{-1} \\
\bar{X} \pm \mathrm{SE}\end{array}$ & $\begin{array}{c}15-25 \mu \mathrm{mol} \mathrm{m}^{-2} \mathrm{~s}^{-1} \\
\bar{X} \pm \mathrm{SE}\end{array}$ \\
\hline \multicolumn{4}{|l|}{ Muhlenbergia frondosa $($ no. $=10)$ : } \\
\hline Chl content $\ldots . . . \ldots \ldots \ldots$ & $8.80 \pm 1.68 \mathrm{a}$ & $23.02 \pm 2.80 b$ & $29.68 \pm 2.51 \mathrm{c}$ \\
\hline $\mathrm{Chl} \mathrm{a/b}$ ratio & $3.39 \pm .33 a$ & $3.34 \pm .28 \mathrm{a}$ & $3.06 \pm .17 b$ \\
\hline \multicolumn{4}{|l|}{ M. sobolifera $($ no. $=10)$ : } \\
\hline Chl content $\ldots \ldots \ldots$ & $9.37 \pm 1.40 \mathrm{a}$ & $25.13 \pm 4.06 \mathrm{~b}$ & $31.61 \pm 1.68 \mathrm{c}$ \\
\hline $\mathrm{Chl} \mathrm{a/b}$ ratio $\ldots \ldots \ldots \ldots \ldots \ldots \ldots \ldots$ & $3.40 \pm .24 \mathrm{a}$ & $3.34 \pm .24 a$ & $2.99 \pm .23 b$ \\
\hline \multicolumn{4}{|l|}{ M. schreberi $($ no. $=6)$ : } \\
\hline Chl content $\ldots . . .$. & $10.58 \pm 1.30 \mathrm{a}$ & $27.67 \pm 2.7 b$ & $5.92 \pm 1.42 c$ \\
\hline $\mathrm{Chl} \mathrm{a/b}$ ratio & $3.42 \pm .10 \mathrm{a}$ & $3.30 \pm .16 \mathrm{~b}$ & $3.10 \pm .57 \mathrm{~b}$ \\
\hline \multicolumn{4}{|l|}{ M. cuspidata $($ no. $=4$ ): } \\
\hline Chl content $\ldots . . .$. & $14.69 \pm 3.62 \mathrm{a}$ & $19.40 \pm 3.00 b$ & $10.00 \pm 1.20 \mathrm{c}$ \\
\hline $\mathrm{Chl} \mathrm{a/b}$ ratio & $3.80 \pm .23$ & $4.00 \pm .45$ & $4.40 \pm .95$ \\
\hline
\end{tabular}

NOTE.-Only means with different letters differ significantly $(P<.05$, LSD). 


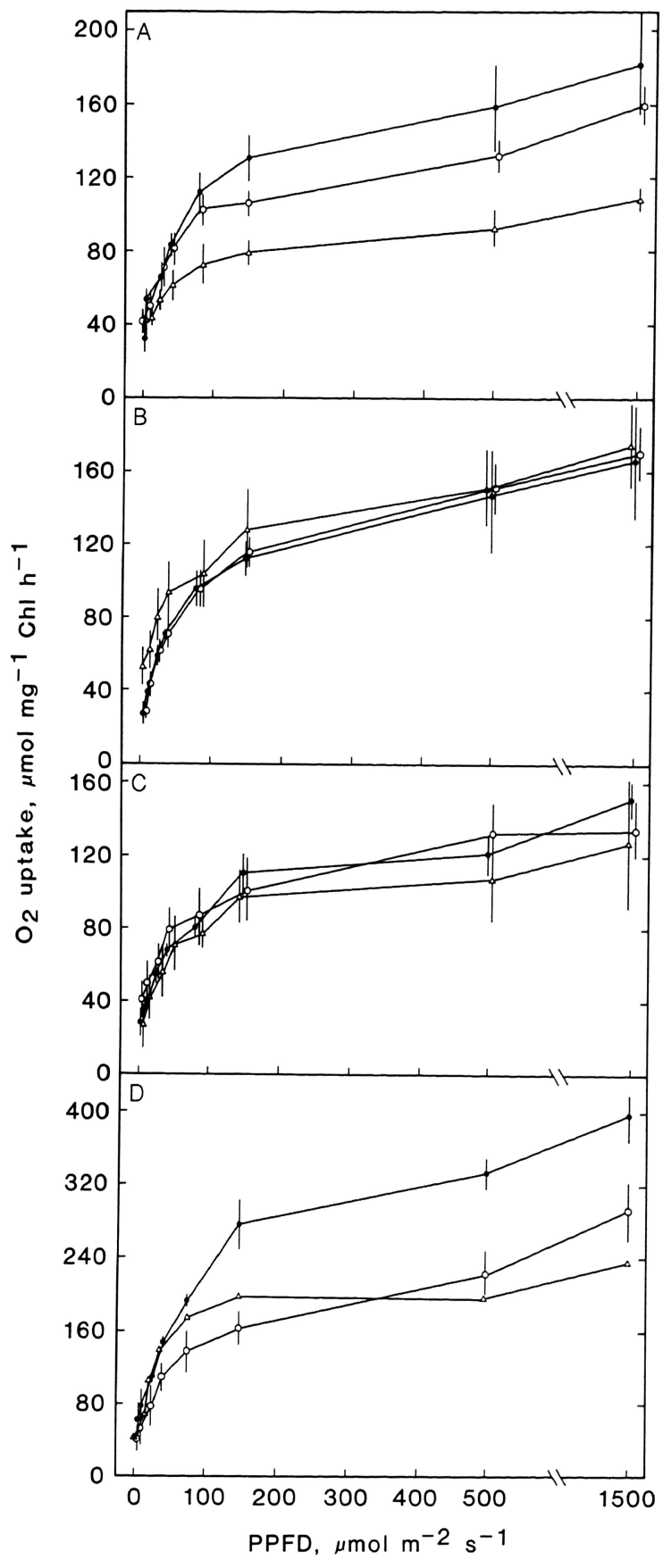

FIG. 5.-Oxygen uptake rates as a function of PPFD in photosystem I electron transport from DCIP to MV in A, Muhlenbergia frondosa; $B, M$. sobolifera: $C, M$. schreberi; and $D$, $M$. cuspidata. Plants were grown for 28-35 days at the following PPFD levels: $-\mathrm{High}=1,500 \mu \mathrm{mol} \mathrm{m}^{-2} \mathrm{~s}^{-1}$. $\bigcirc, \mathrm{Me}-$ dium $=150 \mu \mathrm{mol} \mathrm{m}{ }^{-2} \mathrm{~s}^{-1} . \Delta$, Low $=15-25 \mu \mathrm{mol} \mathrm{m}^{-2} \mathrm{~s}^{-1}$. Data are means and $\mathrm{SE}$ of three plants.

cuspidata were not metabolically damaged when grown at low PPFD, although $\mathrm{CO}_{2}$-uptake rates were ca. $80 \%$ lower than when grown at high PPFD. Photosynthesis apparently was limited by stomatal conductance (FARQUHAR and SHARKEY 1982). On the other hand, the magnitude of the reduction in
A in plants grown at low PPFD indicated that, although they appeared undamaged, they were not harvesting enough PPFD to grow well at such reduced levels. This concurred with observations that $M$. cuspidata died at the lowest PPFD before the end of the 38-day growth period (SMITH and MARTIN 1987).

The low quantum yields of $M$. cuspidata relative to other $\mathrm{C}_{4}$ plants (EHLERINGER and BJÖRKMAN 1977; WARD and WOOLHOUSE 1986) may be the result of a glaucous, reflective leaf surface. Leaf pubescence can reduce absorption of PPFD by $20 \%-70 \%$ (EHLERINGER and BJÖRKMAN 1978). The lack of response to a decrease in PPFD indicates that $M$. cuspidata cannot increase its light utilization efficiency with decreasing growth light level. This is consistent with results for other high-light plants (MONSON et al. 1982; PEARCY and EHLERINGER 1984).

Muhlenbergia frondosa, $M$. sobolifera, and $M$. schreberi are shade adapted to some degree. None of the three suffered a reduction in maximum A between the high and medium PPFD growth regimes. While the photosynthetic rates are lower (ca. $18 \mu \mathrm{mol} \mathrm{m}^{-2} \mathrm{~s}^{-1}$ ) than for most $\mathrm{C}_{4}$ plants, they are comparable with those observed in other $\mathrm{C}_{4}$ species from shaded habitats (ROBICHAUX and PEARCY 1980; WINTER et al. 1982; WARD and WOOLHOUSE 1986). Although the low PPFD plants of the understory species had lower $A$ at $1,500 \mu \mathrm{mol} \mathrm{m} \mathrm{m}^{-2} \mathrm{~s}^{-1}$, the degree of reduction was much less than that observed in $M$. cuspidata. In addition, the saturation of A with respect to PPFD in all but $M$. cuspidata is atypical of other $\mathrm{C}_{4}$ plants, which, under optimal growth conditions, show no photosynthetic saturation at full sunlight (PEARCY et al. 1982).

Changes in quantum yield indicate a greater efficiency of light utilization at low PPFD than at high PPFD in $M$. frondosa and $M$. sobolifera, with values increasing with decreasing growth PPFD. These changes correlate with a similar increase in pigment concentrations.

The discrepancy in A between plants of $M$. schreberi from the medium PPFD regime and those from the high PPFD treatment is difficult to interpret in view of the optimal growth of this species at the highest PPFD level (SMITH and MARTIN 1987). The changes in quantum yields with PPFD in $M$. schreberi, however, are consistent with the observed responses of photosynthesis and pigments. The low quantum yield at high PPFD may be the result of photoinhibition of the photosynthetic apparatus (BJÖRKMAN 1981), whereas the low value in plants grown at low light may reflect an inability to increase pigment levels adequately (ÖQUIST et al. 1982).

Growth PPFD for $M$. sobolifera had no differential effect on either maximum $A$ or the level of PPFD at which A saturated, indicating that this species cannot utilize increased levels of PPFD. This 
agrees with the growth study in which this species exhibited equal biomass production at high and medium PPFD (SMITH and MARTIN 1987). These findings, coupled with quantum yields and chl concentrations that increased with decreasing growth PPFD, indicate that $M$. sobolifera is well adapted to the deep shade of forest understories.

\section{RESPONSES OF $\mathrm{A}_{\text {mes }} / \mathrm{A}$ TO PPFD}

The values for $\mathrm{A}_{\text {mes }} / \mathrm{A}$ in $M$. cuspidata are in agreement with published values for six $\mathrm{C}_{4}$ species (LONGSTRETH et al. 1985). In the three understory species, however, $A_{\text {mes }} / A$ is much lower because (1) chlorophyllous mesophyll tissue was extremely limited (SMITH and MARTIN 1987), and (2) bundle sheath cells, which were included in measurements made by LONGSTRETH et al. (1985), were intentionally excluded in this study since they are not exposed to atmospheric $\mathrm{CO}_{2}$ (STAMP et al. 1985). However, meaningful comparisons of $\mathrm{A}_{\text {mes }} / \mathrm{A}$ ratios can be made between the species and plants grown at different PPFD levels in our study.

In both $M$. cuspidata and $M$. frondosa, the increase in $\mathrm{A}_{\text {mes }} / \mathrm{A}$ with increasing $\mathrm{A}$ is consistent with results for other species grown at high and low PPFD (NOBEL et al. 1975; LONGSTRETH et al. 1985). However, $M$. sobolifera and $M$. schreberi did not show a consistent positive correlation between $A$ and $A_{\text {mes }} / A$. Similar results have been reported for other $\mathrm{C}_{4}$ understory species (PEARCY et al. 1982; WARD and WOOLHOUSE 1986). Photosynthetic responses of $M$. sobolifera and $M$. schreberi evidently are limited by factors other than, or in addition to, mesophyll surface area. It is apparent that not all plants respond to changing light levels only by alteration of leaf morphology.

\section{PIGMENT RESPONSES TO PPFD}

The increase in chl concentration in response to decreasing PPFD in $M$. frondosa and $M$. sobolifera is a typical response of shade plants (BJÖRKMAN and HOLMGREN 1963; JURIK et al. 1979). In contrast, the chl concentration of sun plants either remains relatively unchanged over a range of PPFD (BJÖRKMAN 1981) or declines with severe shading (ÖQUIST et al. 1982). The response of $M$. frondosa and $M$. sobolifera clearly is atypical of sun plants. Although $M$. schreberi exhibits a similar increase in chl concentration from high to medium PPFD, its lack of response to the lowest PPFD regime indicates that it is limited in its capacity to adjust. The pigment response of $M$. cuspidata is more typical of those of sun plants. This species exhibited weaker increases in total chl in response to medium-growth PPFD and then a decline at the lowest growth PPFD level. This is an indication of the poor condition of the plants. In all growth experiments in which the other species reached maturity (ca. 38 days; SMITH and MARTIN 1987), M. cuspidata died at this PPFD level.
The low chl a/b ratios in $M$. frondosa and $M$. sobolifera at low-growth PPFD are consistent with their ability to tolerate shaded conditions. Low chl $\mathrm{a} / \mathrm{b}$ ratios at low-growth PPFD indicate an increase in size of the light-harvesting complex (ALBERTE and THORNBER 1974). Although existing data for $\mathrm{chl} \mathrm{a} / \mathrm{b}$ ratios in sun and shade plants are not always definitive, sun plants generally do not respond with as great a reduction in $\mathrm{a} / \mathrm{b}$ ratios as do shade plants (BJÖRKMAN 1981).

The increase in chl a/b ratios of $M$. cuspidata in response to decreasing PPFD during growth indicates a lack of adaptive adjustment in pigment concentrations to low levels of PPFD. In $M$. schreberi a significant decrease in chl $\mathrm{a} / \mathrm{b}$ ratio occurs at medium PPFD. However, as with chl concentration, chl a/b ratios in this species do not decrease in response to the lowest growth PPFD level. This implies that it is intermediate between $M$. cuspidata from exposed habitats and both $M$. frondosa and $M$. sobolifera in its ability to adjust its pigments in response to decreasing PPFD.

\section{PHOTOSYSTEM I ELECTRON TRANSPORT}

The rates of photosystem I activity for the species in this study are comparable to those of spinach, barley, and several algae (CHUA 1971; KATOH 1972; PLESNIČAR and BENDALL 1973). The increase in electron transport through photosystem I in response to increased growth PPFD in the sun species $M$. cuspidata is consistent with results for other high-light species (BOARDMAN 1972; BJÖRKMAN 1981). Electron transport in $M$. cuspidata and $M$. frondosa responds similarly to increasing PPFD, but the maximum rates of $M$. cuspidata are twice as high as any of the other species in this study. The proportional decrease in maximum electron transport for plants of $M$. frondosa grown at the lowest PPFD level is less than that for $M$. cuspidata grown at the same PPFD level. This indicates that $M$. frondosa is more flexible in its electron-transport capacity than $M$. cuspidata, though less successful at utilizing high PPFD. These results support the photosynthetic data, in which a similar response of $\mathrm{A}$ to increasing growth PPFD is observed. Both $M$. frondosa and $M$. cuspidata have lower oxygen-uptake rates at the lower growth PPFD levels than $M$. sobolifera and $M$. schreberi. The latter species, though demonstrating lower electron-transport rates at the highest instantaneous PPFD level than $M$. cuspidata, have rates equally high for all growth PPFD. In $M$. sobolifera, this conforms to the pattern in the photosynthetic data.

\section{Acknowledgments}

We thank T. RANKER for advice concerning the statistical analyses used in this study. This investigation was supported by University of Kansas General Research allocation 3397-XO-0038 and Biomedical Sciences Support grant RR07037. 


\section{LITERATURE CITED}

Agata, W., S. HakoYama, and Y. Kawamitsu. 1985. Influence of light intensity, temperature and humidity on photosynthesis and transpiration of Sasa nipponica and Arundinaria pygmaea. Bot. Mag. (Tokyo) 98:125-135.

AlberTe, R. S., and J. P. THORNBER. 1974. The correlation between chlorophyll $\mathrm{a} / \mathrm{b}$ ratios and proportions of chlorophyll protein complexes in green plants. Plant Physiol. 53:5563.

BJÖRKMAN, O. 1981. Responses to different quantum flux densities. Pages 57-107 in A. PIRSON and M. H. ZimmermanN, eds. Encyclopedia of plant physiology. Vol. 12A. SpringerVerlag, New York.

BJÖRKMAN, O., N. K. BoARdman, J. M. Anderson, S. W. THORPE, D. J. GOODCHILD, and N. A. PYLEOTIS. 1972. Effects of light intensity during growth of Atriplex patula on the capacity of photosynthetic reactions, chloroplast components and structures. Carnegie Inst. Wash. Yrbk. 71:115-135.

BJöRKMAN, O., and P. HOLMGREN. 1963. Adaptability of the photosynthetic apparatus to light intensity in ecotypes from exposed and shaded habitats. Physiol. Plant. 16:889-914.

BOARDMAN, N. K. 1972. Photochemical properties of a photosystem II subchloroplast fragment. Biochim. Biophys. Acta 283:469-482.

1977. Comparative photosynthesis of sun and shade plants. Annu. Rev. Plant Physiol. 28:355-377.

BROWN, K. W. 1968. Experimental considerations for the measurement of photosynthetic rates by means of carbon dioxide exchange in leaf chambers. Neb. Coll. Agr. Home Econ. Agr. Exp. Sta., Lincoln Progr. Rep. 66:1-40.

BRown, W. V. 1977. The Kranz syndrome and its subtypes in grass systematics. Mem. Torrey Bot. Club 23:1-97.

Снавот, B. F., and J. F. Снавот. 1977. Effect of light and temperature on leaf anatomy and photosynthesis in Fragaria vesca. Oecologia 26:363-377.

ChUA, N. 1971. The methyl viologen-catalyzed Mehler reaction and catalase activity in blue-green algae and Chlamydomonas reinhardi. Biochim. Biophys. Acta 245:277-287.

EHLERINGER, J. R., and O. BJÖRKMAN. 1977. Quantum yields for $\mathrm{CO}_{2}$ uptake in $\mathrm{C}_{3}$ and $\mathrm{C}_{4}$ plants: dependence on temperature, $\mathrm{CO}_{2}$ and $\mathrm{O}_{2}$ concentration. Plant Physiol. 59:86-90.

1978. A comparison of photosynthetic characteristics of Encelia species possessing glabrous and pubescent leaves. Plant Physiol. 62:185-190.

FARQUHAR, G. D., and T. D. SHARKEY. 1982. Stomatal conductance and photosynthesis. Annu. Rev. Plant Physiol. 33:317-345.

FARQUHAR, G. D., and S. Von CAEMMERER. 1982. Modelling of photosynthetic response to environmental conditions. Pages 549-587 in O. L. LANGe, P. S. Nobel, C. B. Osmond, and H. ZIEGLER, eds. Encyclopedia of plant physiology. Vol. 12B. Springer-Verlag, New York.

JuriK, T. W., J. F. Сhaвот, and B. F. Сhавот. 1979. Ontogeny of photosynthetic performance in Fragaria virginiana under changing light regime. Plant Physiol. 63:542-547.

KATOH, S. 1972. Studies on electron transport associated with photosystem I: rate of plastocyanin in methyl viologen photoreduction in French press-treated chloroplasts. Biochim. Biophys. Acta 283:293-301.

LONGSTRETH, D. J., J. A. BolanOS, and R. H. GodDARD. 1985. Photosynthetic rate and mesophyll surface area in expanding leaves of Alternanthera philoxeroides grown at two light levels. Am. J. Bot. 72:14-19.

Longstreth, D. J., T. L. HarTsock, and P. S. Nobel. 1981. Light effect on leaf development and photosynthetic capacity of Hydrocotyle bonariensis Lam. Photosyn. Res. 2:195-199.

Martin, C. E., K. W. McLeod, C. A. EAdes, and A. F. Pitzer. 1985. Morphological and physiological responses to irradi- ance in the CAM epiphyte Tillandsia usneoides L. (Bromeliaceae). Bot. Gaz. 146:489-494.

Martin, C. E., and A. K. ZeE. 1983. C 3 photosynthesis and Crassulacean acid metabolism in a Kansas rock outcrop succulent, Talinum calycinum Engelm. (Portulacaceae). Plant Physiol. 73:718-723.

Monson, R. K., R. O. LitTlejohn, JR., and G. J. Williams III. 1982. The quantum yield for $\mathrm{CO}_{2}$ uptake in $\mathrm{C}_{3}$ and $\mathrm{C}_{4}$ grasses. Photosyn. Res. 3:153-159.

NOBEL, P. S. 1976. Photosynthetic rates of sun versus shade leaves of Hyptis emoryi Torr. Plant Physiol. 58:218-223.

NoBEL, P. S., and D. J. LONGSTRETH. 1981. Effect of environmental factors on leaf anatomy, mesophyll cell conductance and photosynthesis. Pages 245-254 in G. AKOYUNOGLOU, ed. Photosynthesis. Vol. 6. Balaban Int. Sci. Serv., Philadelphia.

Nobel, P. S., L. J. ZaragozA, and W. K. Smith. 1975. Relation between mesophyll surface area, photosynthetic rate, and illumination level during development for leaves of Plectranthus parviflorus Henckel. Plant Physiol. 55:10671070.

ÖQuist, G., L. BRunes, and J. E. Hallgren. 1982. Photosynthetic efficiency of Beluta pendula acclimated to different quantum flux densities. Plant Cell Environ. 5:9-15.

ÖQUIST, G., and N. O. Hellgren. 1976. The photosynthetic electron capacity of chloroplasts prepared from needles of unhardened and hardened seedlings of Pinus silvestris. Plant Sci. Lett. 7:359-369.

PearCy, R. W., and J. R. Ehleringer. 1984. Comparative ecophysiology of $\mathrm{C}_{3}$ and $\mathrm{C}_{4}$ plants. Plant Cell Environ. 7:1-13.

PeARCY, R. W., K. Osteryoung, and D. Randall. 1982. Carbon dioxide exchange characteristics of $\mathrm{C}_{4}$ Hawaiian $\mathrm{Eu}$ phorbia species native to diverse habitats. Oecologia 55:333341.

PlesNiČAR, M., and D. S. Bendall. 1973. Some evidence on the site of action of plastocyanin in the photosynthetic electron-transport chain between cytochromes $\mathrm{f}$ and P700. Eur. J. Biochem. 34:483-488.

RobichauX, R. H., and R. W. Pearcy. 1980. Environmental characteristics, field water relations and photosynthetic responses of $\mathrm{C}_{4}$ Hawaiian Euphorbia species from contrasting habitats. Oecologia 47:99-105.

RoBinson, H. H., and C. F. Yocum. 1980. Cyclic photophosphorylation reactions catalyzed by ferredoxin, methyl viologen and anthraquinone sulfonate. Biochem. Biophys. Acta 590:97-106.

SÉSTÁK, Z., J. ČATSKÝ, and P. G. JARVIS. 1971. Plant photosynthetic production: manual of methods. Junk, The Hague. $818 \mathrm{pp}$.

SMith, M., and C. E. MarTin. 1987. Growth and morphological responses to irradiance in three forest understory species of the $\mathrm{C}_{4}$ grass genus Muhlenbergia. Bот. GAZ. 148:141148.

SoKal, R. R., and F. J. RohlF. 1981. Biometry. 2d ed. W. H. Freeman, San Francisco. 859 pp.

Stamp, P., R. Thiraporn, and G. GeISLER. 1985. Anatomy of chlorenchyma cells in maize lines developed at different latitudes and grown at sub- and supraoptimal temperatures. Physiol. Plant. 63:159-162.

WARD, D. A., and H. W. WOOLHOUSE. 1986. Comparative effects of light during growth on the photosynthetic properties of NADP-ME type $\mathrm{C}_{4}$ grasses from open and shaded habitats: gas exchange, leaf anatomy and ultrastructure. Plant Cell Environ. 9:261-270.

WINTER, K., M. R. SCHMITT, and G. E. EdWARds. 1982. Microstegium vimineum, a shade adapted $\mathrm{C}_{4}$ grass. Plant Sci. Lett. 24:311-318. 